\title{
Ekstraksi dan Karakterisasi Alergenisitas Protein Belut Sawah (Monopterus javanensis La Cepéde, 1800) untuk Pembuatan Reagen Uji Tusuk Kulit Extraction and Characterization of Rice Eel (Monopterus javanensis La Cepéde, 1800) Protein Allergenicity for the Production of Skin Prick Test Reagents
}

\author{
Lusiana $a^{*}$, Fransiska Zakaria Rungkat ${ }^{\mathrm{b}}$, Endang Prangdimurtib dan Hendra Wijayac \\ ${ }^{a}$ Mahasiswa S3 Program Studi Ilmu Pangan, Fakultas Teknik dan Teknologi Pertanian IPB, Jurusan Kimia, FMIPA \\ Universitas Bengkulu, Indonesia
}

${ }^{b}$ Program Studi Ilmu Pangan, Fakultas Teknologi Pertanian IPB, JL. Raya Dramaga Bogor Indonesia

`Balai Besar Industri Agro, Jl. Ir. Juanda No. 11, Bogor, Jawa Barat, Indonesia

\begin{abstract}
Riwayat Naskah:
ABSTRAK: Penelitian ini bertujuan untuk mengisolasi protein alergen belut segar (BS) dan

Diterima 092021

Direvisi 112021

Disetujui 112021 belut rebus (BR) dengan buffer Tris Glisin (TG), Tris Glisin DTT (TGD) dan Phosphat buffer saline (PBS) serta mengkarakterisasi alergenisitas isolat protein dengan uji elektroforesis SDS-PAGE, ELISA dan immunoblotting. Rendemen protein yang dihasilkan pada BSTG, BSTGD dan BSPBS sebesar $2166 \mathrm{mg} / \mathrm{L}, 2083 \mathrm{mg} / \mathrm{L}$ dan $2284 \mathrm{mg} / \mathrm{L}$. Rendemen ekstrak protein BRTG, BRTGD, BRPBS adalah $1445 \mathrm{mg} / \mathrm{L}, 1805 \mathrm{mg} / \mathrm{L}$ dan $1207 \mathrm{mg} / \mathrm{L}$. Hasil SDSPage menunjukkan profil protein BSTG memiliki 16 pita protein dengan bobot molekul dari $22 \mathrm{kDa}-233 \mathrm{kDa}$ dan BSTGD sebanyak 6 pita dengan bobot molekul $22 \mathrm{kDa}-112 \mathrm{kDa}$, BSPBS sebanyak 16 pita dengan bobot molekul $22 \mathrm{kDa}-93 \mathrm{kDa}$, BRTG memiliki 7 pita dengan berat molekul $24 \mathrm{kDa}-267 \mathrm{kDa}$, BRTGD terdeteksi sebanyak 10 pita dengan berat molekul 24 kDa-235 kDa, BRPBS memiliki 10 pita protein dengan berat molekul $24 \mathrm{kDa}-297 \mathrm{kDa}$. Hasil immunobloting dari 10 subjek yang positif alergi menunjukkan ada 3 subjek yang memberikan reaksi positif yaitu subjek 2 pada BSPBS, subjek 4 pada BSTG, BSTGD dan BSPBS serta subjek 8 pada BSTGD, BSPBS, BRTG dan BRTGD. Buffer PBS dapat meningkatkan rendemen ekstrak protein belut dan meningkatkan alergenitas reagen sehingga dapat digunakan sebagai buffer untuk pembuatan reagen uji tusuk kulit.
\end{abstract}

Kata kunci: alergen, belut sawah (Monopterus Javanensis La Cepéde, 1800), ELISA immunoblotting, SDS-page

ABSTRACT: This study aims to isolate allergen protein from fresh and boiled eel using Tris Glisin (TG), Tris Glisin DTT (TGD) and Phosphate buffer saline (PBS) and characterize the allergenicity of the protein isolates by SDS-PAGE, ELISA and immunoblotting. The yield BSTG, BSTGD and BSPBS, were $2166 \mathrm{mg} / \mathrm{L}, 2083 \mathrm{mg} / \mathrm{L}$ and $2284 \mathrm{mg} / \mathrm{L}$. BRTG, BRTGD, BRPBS were $1445 \mathrm{mg} / \mathrm{L}, 1805 \mathrm{mg} / \mathrm{L}$ and $1207 \mathrm{mg} / \mathrm{L}$. The SDS PAGE results showed that BSTG have 16 bands of protein with a molecular weight (MW) of $22 \mathrm{kDa}-233 \mathrm{kDa}, 6$ bands of BSTGD with MW of $22 \mathrm{kDa}-112 \mathrm{kDa}$ and 16 bands of BSPBS with MW $22 \mathrm{kDa}-93 \mathrm{kDa}$. BRTG has 7 bands with MW of $24 \mathrm{kDa}-267 \mathrm{kDa}$, BRTGD detected as many as 10 bands with MW of $24 \mathrm{kDa}-235 \mathrm{kDa}$ and BRPBS has 10 bands with MW of $24 \mathrm{kDa}-297 \mathrm{kDa}$. The immunobloting results of 10 positively allerged subjects showed that 3 subjects gave positive reactions to allergens, i.e. subjects 2 for BSPBS, subjects 4 for BSTG, BSTGD, BSPBS and subjects 8 for BSTGD, BSPBS, BRTG and BRTGD. The results showed that PBS increased the protein extract yield and its allergenicity and could be used as a buffer for skin prick test reagents

Keywords: alergen, Monopterus Javanensis La Cepéde, 1800), ELISA, immunoblotting SDS-page

\footnotetext{
Kontributor utama

Email : lusiana@unib.ac.id
} 


\section{Pendahuluan}

Alergi pangan merupakan suatu kondisi yang disebabkan oleh respons imun yang tidak sesuai terhadap protein makanan yang mengakibatkan sintesis antibody IgE secara berlebihan (Zakaria et al. 1993 I). IgE merupakan antibodi yang berfungsi mengaktifkan sistim inflamasi sehingga sintesis IgE yang tidak terkontrol dapat menghasilkan inflamasi alergi. Alergi pangan merupakan jenis alergi yang mengkhawatirkan dengan prevalensi yang tertinggi pada masa bayi dan anak usia dini (Chapman et al. 2006, Zakaria et al. 1993 II). Salah satu respons karena alergi pangan adalah terjadinya reaksi sistem kekebalan tubuh atau imunitas (Yusnawan 2013). Reaksi ini ditimbulkan karena konsumsi sumber alergen, terutama berupa protein, yang dicirikan dengan terbentuknya antibodi IgE spesifik alergen tertentu (Van Hangel 2007).

Gejala yang timbul akibat mengkonsumsi protein alergen antara lain adalah kulit kemerahan, gatalgatal pada mulut, bibir menebal, mual, muntah dan diare, hidung berair, bersin, organ pernafasan terasa menyempit, pembengkakan pada laring, sulit bernafas penurunan tekanan darah, pusing hingga pingsan, gerakan dan denyut nadi yang tidak teratur (Sampson 2002).

Untuk menghindari alergi, masyarakat cenderung menghindari makanan yang diduga menimbulkan alergi (Sampson 2002). Makanan tersebut merupakan sumber nutrisi yang sangat diperlukan untuk pertumbuhan dan perkembangan seseorang (Purbasari 2012). Oleh karena itu diperlukan suatu uji diagnosis alergi. Tes alergi yang dilakukan untuk mengetahui jenis pangan yang menyebabkan seseorang tersebut alergi adalah dengan Skin Prick Test atau uji tusuk kulit. Uji tusuk kulit adalah tes diagnostik in vivo terhadap alergen hisap dan makanan, untuk mendeteksi antigen yang terlibat dalam reaksi hipersensitifitas tipe-I yang dimediasi IgE (Ilyas dan Waspodo 2010).

Pereaksi yang digunakan untuk uji tusuk kulit adalah ekstrak protein pangan yang selama ini masih diimpor dari luar negeri sehingga harganya relatif mahal (Wijaya et al. 2014). Pada penelitian ini memanfaatkan bahan pangan asli Indonesia salah satunya adalah belut sawah yang jumlahnya cukup melimpah untuk dijadikan ekstrak alergen. Belut sawah (Monopterus javanensis La Cepéde, 1800) memiliki sumber protein tinggi, lemak, vitamin, dan mineral yang sangat baik. Komposisi kimia yang paling banyak terdapat pada belut adalah protein (Astiana et al. 2016).

Menurut Vissers et al. (2011), pengolahan makanan dapat menurunkan atau meningkatkan alergenitas suatu bahan pangan karena proses termal suatu protein dapat menyebabkan perubahan pada struktur protein yang dapat menyebabkan perubahan dalam alergenitasnya. Penelitian yang dilakukan Zakaria (1998) menunjukkan bahwa proses pengolahan bahan pangan dapat meningkatkan alergenitas. Alergenitas protein dapat diturunkan atau dinaikkan dengan pengolahan karena dapat mengubah struktur alergen dan membuat alergen lebih tidak dikenali antibodi (Suseno et al. 2016). Belut sawah yang digunakan dalam penelitian ini diolah dengan cara direbus karena menurut Sundari et al. (2015), retensi protein bahan pangan yang mengalami perebusan lebih tinggi dibandingkan bahan pangan yang diolah dengan cara lain.

Salah satu cara untuk mendapatkan isolat protein diperlukan pelarut buffer yang sesuai agar menghasilkan rendemen yang tinggi. Menurut Ma et al. (2017) penggunaan pelarut yang sesuai berperan penting dalam proses ekstraksi protein karena dapat meningkatkan rendemen dan meningkatkan aktivitas dari protein alergen yang dihasilkan. Pada penelitian ini, ekstraksi protein pada belut sawah menggunakan variasi 3 macam pelarut atau buffer yaitu Tris Glisin (TG), Tris Glisin DTT (TGD) dan Phosphate buffer saline (PBS). Penelitian ini bertujuan untuk mengisolasi protein belut sawah dan mengkarakterisasi alergenitas isolat protein yang dihasilkan dengan sodium dedocyl sulfatepolyacrylamide gel (SDS-PAGE), enzyme-linked immmunosorbent assay (ELISA), immunoblotting dan menguji reaktivitas isolat protein belut sawah sebagai alergen untuk diagnosis alergi pangan dengan metode uji tusuk kulit.

\section{Bahan dan Metode}

\subsection{Bahan}

Belut sawah diperoleh dari persawahan masyarakat di kampung Cisalopa Kecamatan Caringin Kab. Bogor. Bahan kimia yang digunakan antara lain bufer fosfat $\mathrm{pH} \mathrm{7,} \mathrm{bufer} \mathrm{tris} \mathrm{pH} 8,8$ dan pH 6,8, etanol $95 \%, \mathrm{NaOH}$, PBS (phosphate bufer saline), $\mathrm{K}_{2} \mathrm{SO}_{4}, \mathrm{HgO}, \mathrm{H}_{2} \mathrm{SO}_{4}$, heksana, $\mathrm{HCl}, \mathrm{AgNO}_{3}$, $\mathrm{AgCl}$, natrium fosfat, amonium persulfat (APS), metanol, gliserol, $\beta$-merkaptoetanol, bromfenol blue, kalium sulfat, etanol 95\%, asam fosfat, bufer fosfat, asam asetat glasial, akuades, $\mathrm{NaCl}, \mathrm{H}_{3} \mathrm{BO}_{3}, \mathrm{Na}_{2} \mathrm{~S}_{2} \mathrm{O}_{3}$, indikator metilen red-metilen blue, tween-20, histamin, TEMED (N,N,N',N'-tetramethyl-ethane-1,2diamine), tris base, SDS (sodium dodecyl sulphate), BSA (bovine serum albumin), akrilamid, glisin, bufer karbonat-karbonat 0,05 M pH 9.6, TBS (tris bufer saline), PBST (phosphate bufer saline-Tween 20 0,05\%), DTT (dithitotriol), tris, glisin, akuabides, coomasie brilliant blue G-250, antibodi anti IgE manusia berlabel enzim HRP (Horseradish peroksidase), substrat DAB (3,3-Diaminobenzidine), , $\mathrm{N}, \mathrm{N}$-metilen-bisakrilamid, low molecular weight 
Citation: Lusiana, Rungkat, F. J., Prangdimurti, E., \& Wijaya, H. (2021). Ekstraksi dan karakterisasi alergenisitas protein belut sawah (Monopterus javanensis La Cepéde, 1800) untuk pembuatan reagen uji tusuk kulit. Warta IHP, 38(2), 108-116

Halaman | 110

protein (LMW) Fermentasi ${ }^{\circledR}, 50 \%$ Gliserol, Buffer bikarbonat $\mathrm{pH}$ 8. Serum darah diperoleh dari 10 responden yang alergi terhadap bahan makanan.

\subsection{Alat}

Peralatan yang digunakan adalah SDS-PAGE Bio Rad Mini-Protean II, Immunoblotting Mini Mini Trans-Blot $\AA^{2}$ Electrophoretic Transfer, ELISA Reader spektrofotometer UV-VIS, nitrocellulose membranes for blotting pore size $0.45 \mu \mathrm{m}$, size $15 \mathrm{~cm} \times 15 \mathrm{~cm}$ (Sigma N8267), jarum marrow brow, pH meter, vortex, mikropipet, mikrotube $5 \mu \mathrm{L}$ hingga $1000 \mu \mathrm{L}$ stirrer, vial, kertas filter $0,22 \mu \mathrm{m}$, kertas saring Whatman No.1, kertas saring biasa, tabung reaksi, kaca arloji, gelas ukur, labu takar, gelas piala, erlenmeyer, cawan petri dan peralatan gelas lainnya.

\subsection{Metode}

\subsubsection{Ekstraksi protein belut sawah (Ma et al. 2017)}

Daging segar belut sawah dipisahkan dari bagianbagian tubuh yang lain yaitu kepala dan tulang dengan cara difillet dan dibersihkan kemudian dihaluskan dengan blender. Untuk perlakuan, daging segar belut sawah yang telah dipisahkan dan dibersihkan direbus selama 5 menit. Sampel daging belut sawah yang segar dan yang direbus masingmasing sebanyak $300 \mathrm{~g}$ dihomogenisasi sambil dishaker pada suhu konstan $40^{\circ} \mathrm{C}$ menggunakan 3 macam buffer. Buffer 1 yaitu campuran Tris, glisin (TG). Buffer 2 yaitu campuran Tris, glisin dan DTT (TGD). Buffer 3 yaitu phosphate buffered saline (PBS). Belut segar buffer Tris Glisin (BSTG), belut segar buffer Tris Glisin DTT (BSTGD), belut segar buffer PBS (BSPBS), belut rebus buffer Tris Glisin (BRTG), belut rebus buffer Tris Glisin DTT (BRTGD), belut rebus buffer PBS (BRPBS) dikocok dan diekstraksi pada $130 \mathrm{rpm}$ selama 16 jam dan dilanjutkan dengan disentrifuse pada $4000 \mathrm{rpm}$ selama 30 menit. Supernatan yang diperoleh dikumpulkan. Endapan yang dihasilkan diekstraksi kembali masing-masing dengan ketiga pelarut selama 5 jam pada suhu $40^{\circ} \mathrm{C}$ Setelah itu disentrifus pada $4000 \mathrm{rpm}$ suhu $40^{\circ} \mathrm{C}$ selama 30 menit. Supernatan yang diperoleh disatukan dengan supernatan dari hasil sentrifus yang pertama dan didialisis menggunakan akuades selama 24 jam. Akuades diganti sebanyak 2 kali selama dialisis dan dianalis proteinnya dengan metode Bradford (Bradford 1976). Supernatan yang telah didialisis kemudian dikeringkan dengan freeze drier dan bubuk protein ini harus disimpan pada suhu $-20^{\circ} \mathrm{C}$ jika belum diberi perlakuan.

\subsubsection{Analisis profil isolat protein dengan SDS-PAGE (Laemmli 1970; Wijaya et al. 2015)}

Isolat protein belut sawah ditentukan karakteristiknya dengan elektroforesis SDS PAGE menggunakan gel akrilamid. Gel ini terdiri atas dua bagian, yaitu stacking gel dengan konsentrasi akrilamid 5\% dan separating gel dengan konsentrasi akrilamid $12 \%$. Sebanyak 0,1 g isolat protein yang diperoleh dilarutkan dengan masing-masing $2 \mathrm{ml}$ buffer TG, TGD dan PBS. Sebanyak $40 \mu \mathrm{L}$ masingmasing sampel yang sudah dilarutkan dimasukkan ke dalam microtube 0,5 mL dan ditambahkan $10 \mu \mathrm{L}$ masing-masing buffer. Tabung kemudian dipanaskan selama 5 menit dalam air mendidih $100^{\circ} \mathrm{C}$. Standar yang digunakan adalah low molecular weight protein (LMW) Fermentasi® Gel hasil running dipindahkan ke dalam wadah tertutup yang telah berisi pewarna pewarna coomasie brilliant blue G-250.

\subsubsection{Preparasi serum penderita alergi (Wijaya et al. 2014, Astuti et al. 2016)}

Sebanyak 10 penderita alergi pangan diambil serumnya oleh tenaga medis dari klinik Alergi dan Asma Indrajana Jakarta (Kode etik penelitian No.168/IT3.KEPMSM-IPB/SK/2019). Subjek penelitian ini berasal dari desa Cigombong dan desa Cijeruk Kab. Bogor yang alergi terhadap bahan makanan, berjenis kelamin laki-laki dan perempuan berumur 15-45 tahun. Darah ditempatkan dalam tabung tanpa mengandung EDTA dan disentrifus selama 20 menit pada kecepatan 2500 rpm (1250 g). Serum disimpan pada suhu $-20^{\circ} \mathrm{C}$.

\subsubsection{Analisis IgE spesifik serum dengan metode ELISA (Wijaya et al. 2014 dan Kumar et al. 2010)}

Protein belut $(10 \mu \mathrm{g} / \mathrm{mL})$ sebanyak $100 \mu \mathrm{L}$ yang terlarut dalam buffer karbonat-bikarbonat $(0,05 \mathrm{M}$, pH 9,8) dimasukkan ke dalam setiap sumur pada lempeng mikrotiter, kemudian diinkubasi pada suhu $4^{\circ} \mathrm{C}$ selama 1 malam. Sisa sampel pada lempeng mikrotiter dibuang, kemudian lempeng dicuci 5 kali dengan PBST sebanyak $250 \mu \mathrm{L} /$ sumur. Selanjutnya lempeng mikrotiter diblok dengan susu skim 5\% dalam PBST sebanyak $200 \mu \mathrm{L} /$ sumur, dan diinkubasi selama 1 jam pada suhu $37^{\circ} \mathrm{C}$. Lalu lempeng mikrotiter dicuci dengan PBST (250 $\mu \mathrm{L} /$ sumur) sebanyak 5 kali. Serum penderita alergi yang telah diencerkan 1:10 dalam PBST ditambahkan pada lempeng mikrotiter sebanyak $100 \mu \mathrm{L} /$ sumur, selanjutnya diinkubasi selama 1 jam pada suhu $37^{\circ} \mathrm{C}$. Setelah inkubasi, lempeng dicuci dengan PBST $(250 \mu \mathrm{L} /$ sumur $)$ sebanyak 5 kali, kemudian ditambah $100 \mu \mathrm{L} /$ sumur antibodi 
monoklonal mencit anti IgE manusia terkonyugasi HRP terencerkan 1:6000 dalam PBST, lalu diinkubasi selama 1 jam pada suhu $37^{\circ} \mathrm{C}$. Lempeng dicuci dengan PBST (250 $\mu \mathrm{L} /$ sumur) sebanyak 10 kali, dan ditambah substrat TMB sebanyak 100 $\mu \mathrm{L} /$ sumur. Hasil positif ditandai dengan timbulnya warna biru. Setelah 5 menit, reaksi dihentikan dengan menggunakan $\mathrm{H}_{2} \mathrm{SO}_{4} \quad 2 \mathrm{M}$ sebanyak 100 $\mu \mathrm{L} /$ sumur. Optical density (OD) larutan yang telah berubah menjadi berwarna kuning cerah diukur dengan menggunakan ELISA reader pada panjang gelombang $450 \mathrm{~nm}$.

\subsubsection{Immunoblotting (Wijaya et al. 2014)}

Gel hasil elektroforesis yang tidak diwarnai ditransfer ke membran nitroselulosa $(0,45 \mu \mathrm{m})$ yang disusun dalam alat transblotting, lalu diisi dengan buffer transfer. Blotting dilakukan pada $90 \mathrm{~V}$ selama 90 menit. Setelah selesai blotting, membran dilepas dari rangkaian alat dan direndam atau difiksasi dengan metanol 50\% selama 2 menit, lalu diblok dengan susu skim 5\% dalam PBST selama 1 jam pada suhu kamar. Membran dicuci dengan PBST 3 kali, masing-masing selama 5 menit. Setelah dicuci, membran ditambah serum penderita alergi dengan pengenceran 1:10 dalam PBST, selanjutnya diinkubasi selama 2 jam pada suhu kamar. Pencucian dilakukan lagi dengan PBST sebanyak 3 kali, masing-masing selama 5 menit, lalu diberi antibodi dengan pengenceran 1:3000 dalam PBST dan diinkubasi selama 1 jam sambil digoyang pelan. Setelah itu, membran dicuci kembali dengan PBST sebanyak 3 kali masing-masing selama 5 menit, dan ditambah substrat DAB. Satu tablet DAB dilarutkan dengan $10 \mathrm{~mL}$ Tris Buffered Salin (TBS) dengan $\mathrm{pH}$ 7,5. Hasil deteksi positif kompleks protein alergen dengan antibodi ditandai dengan terbentuknya pita berwarna coklat pada membran nitroselulosa dan diukur pitanya dengan software Gelanalyzer 2010a.

\subsubsection{Persiapan ekstrak uji tusuk kulit}

Isolat protein dari BSTG, BSTGD, BSPBS, BRTG, BRTGD dan BRPBS sebanyak 0,2 g dilarutkan dalam $2 \mathrm{~mL}$ masing-masing Buffer disonikasi setiap menit selama 5 menit dan disentrifus pada kecepatan $13000 \mathrm{rpm}$ selama 15 menit. Supernatan disaring dengan kertas filter 0,22 $\mu \mathrm{m}$ dan ditentukan kadar proteinnya dengan metode Bradford. Isolat ini kemudian dilarutkan dalam $50 \%$ gliserol yang mengandung $0,4 \%$ fenol sehingga konsentrasi menjadi $1 \mu \mathrm{g} / \mu \mathrm{L}$ dalam vial $5 \mathrm{~mL}$ steril. Larutan yang diperoleh diuji sterilitas dan mikrobiologis sebelum digunakan untuk uji tusuk kulit.

\subsubsection{Uji tusuk kulit (Maleki et al. 2010, Jeong et al. 2013, Wijaya et al. 2014, Wijaya et al. 2015)}

Uji Tusuk Kulit dilakukan oleh dokter alergolog pada Klinik Alergi dan Asma DR. Indrajana, Jakarta. Subyek penelitian untuk uji tusuk kulit ini adalah 10 orang penderita alergi yang dari hasil wawancara alergi terhadap makanan laut dan kacang-kacangan. Penelitian ini telah lolos kaji etik no. 168/IT3.KEPMSM-IPB/SK/2019. Uji tusuk kulit dilakukan pada lengan bawah bagian volar yang sebelumnya disinfeksi dengan alkohol dan ditandai dengan bolpoin. Sebagai kontrol positif digunakan histamin $1 \mu \mathrm{g} / \mu \mathrm{L}$ dan sebagai kontrol negatif digunakan larutan gliserol-saline 50\%. Tusukan dilakukan dengan kemiringan $45^{\circ}$ menembus lapisan epidermis tanpa menimbulkan pendarahan. Setelah 15-20 menit hasil tes dibaca dengan mengukur bentol yang timbul.

\section{Hasil dan Pembahasan}

\subsection{Ekstraksi protein}

Rendemen ekstrak protein belut segar yaitu BSTG, BSTGD dan BSPBS masing-masingnya adalah yaitu sebesar $2832 \mathrm{mg} / \mathrm{L}, 2766 \mathrm{mg} / \mathrm{L}$ dan 2925 $\mathrm{mg} / \mathrm{L}$. Untuk rendemen ekstrak protein belut rebus yaitu BRTG, BRTGD, BRPBS masing-masingnya adalah $2258 \mathrm{mg} /, 2545 \mathrm{mg} / \mathrm{L}$ dan $2069 \mathrm{mg} / \mathrm{L}$ (Gambar 1). Dari hasil ini terlihat belut segar memiliki rendemen protein yang lebih tinggi dibandingkan dengan rendemen protein fillet yang direbus. Menurut Palupi et al. (2015), proses pemanasan menyebabkan terjadinya perubahan kelarutan protein sehingga mempengaruhi jumlah dan jenis protein yang dapat terekstrak dalam proses isolasi protein.

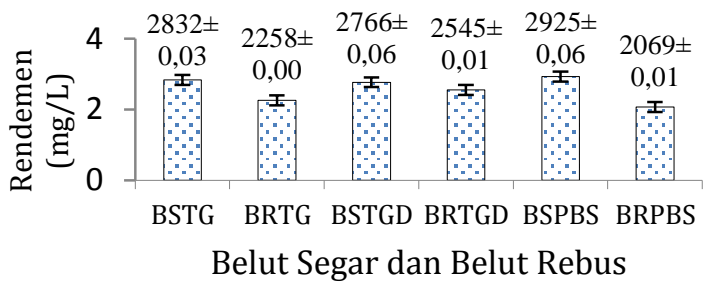

Keterangan: BSTG= Belut Segar Buffer Tris Glisin, BSTGD= Belut Segar Buffer Tris Glisin DTT, BSPBS= Belut Segar Buffer PBS, BRTG = Belut Rebus Buffer Tris Glisin, BRTGD= Belut Rebus Buffer Tris Glisin DTT, BRPBS= Belut Rebus Buffer PBS

Gambar 1. Rendemen ekstrak protein belut sawah

\subsection{Profil isolat protein dengan SDS-PAGE}

Profil isolat protein yang dihasilkan dapat dilihat pada Gambar 2. Hasil SDS PAGE ini kemudian dianalisis dengan software Gelanalyzer 2010a. Hasil analisis menunjukkan bahwa pada BSTG muncul 
pita protein sebanyak 16 pita protein dengan bobot molekul $233 \mathrm{kDa}, 195 \mathrm{kDa}, 157 \mathrm{kDa}, 101 \mathrm{kDa}, 60$ $\mathrm{kDa}, 35 \mathrm{kDa}, 32 \mathrm{kDa}, 30 \mathrm{kDa}, 28 \mathrm{kDa}, 26 \mathrm{kDa}, 24 \mathrm{kDa}$, $23 \mathrm{kDa}$ dan 4 pita dengan bobot molekul $22 \mathrm{kDa}$. BSTGD memiliki 16 pita protein dengan bobot molekul $112 \mathrm{kDa}, 67 \mathrm{kDa}, 36 \mathrm{kDa}, 22 \mathrm{kDa}, 30 \mathrm{kDa}, 28$ $\mathrm{kDa}, 26 \mathrm{kDa}, 2$ pita dengan bobot molekul $24 \mathrm{kDa}, 23$ $\mathrm{kDa}$ dan 6 pita dengan bobot molekul $22 \mathrm{kDa}$. Ekstrak BSPBS memiliki 16 pita protein yaitu 93 kDa, 59 kDa, 34 kDa, 31 kDa, 25 kDa, 24 kDa, 2 pita pada bobot molekul $23 \mathrm{kDa}$ dan 5 pita pada bobot molekul $22 \mathrm{kDa}$. Sampel BRTG memiliki 7 pita protein yang bobot molekulnya $267 \mathrm{kDa}, 2480 \mathrm{kDa}$, $178 \mathrm{kDa}, 80 \mathrm{kDa}, 30 \mathrm{kDa}, 26 \mathrm{kDa}$ dan $24 \mathrm{kDa}$. Pada sampel BRTGD terdeteksi 10 pita protein yaitu 235 $\mathrm{kDa}, 166 \mathrm{kDa}, 77 \mathrm{kDa}, 50 \mathrm{kDa}, 38 \mathrm{kDa}, 31 \mathrm{kDa}, 26$ $\mathrm{kDa}, 25 \mathrm{kDa}$, dan 2 pita protein yang bobot molekulnya $24 \mathrm{kDa}$. Sampel BRPBS memiliki 10 pita protein yaitu $297 \mathrm{kDa}, 221 \mathrm{kDa}, 152 \mathrm{kDa}, 115 \mathrm{kDa}$, $75 \mathrm{kDa}, 29 \mathrm{kDa}, 3$ pita protein yang bobot molekulnya $25 \mathrm{kDa}$ dan $24 \mathrm{kDa}$.

Belut rebus memiliki jumlah pita protein yang lebih sedikit dibandingkan dengan belut segar. Perebusan dapat menurunkan kadar protein dalam bahan pangan karena dalam prosesnya menggunakan suhu tinggi yang menyebabkan denaturasi protein sehingga menurunkan daya larutnya. Hal ini menyebabkan sifat alergenisitasnya juga mengalami perubahan karena proses termal suatu protein dapat menyebabkan perubahan pada struktur protein yang dapat menyebabkan perubahan dalam alergenitasnya (Vissers et al. 2011, Nirbaya et al. 2021). Alergenitas protein dapat diturunkan atau dinaikkan dengan pengolahan karena dapat mengubah struktur alergen dan membuat alergen lebih tidak dikenali antibodi (Suseno et al. 2016, Zakaria 1998 ).

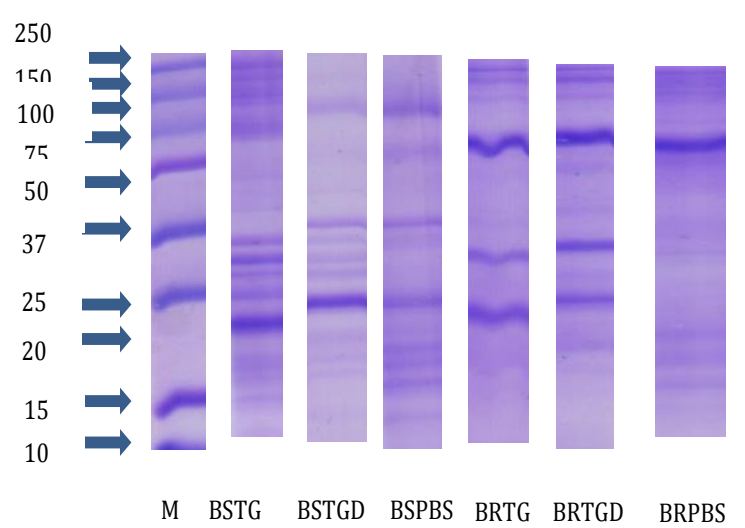

Keterangan: BSTG= Belut Segar Buffer Tris Glisin, BSTGD= Belut Segar Buffer Tris Glisin DTT, BSPBS= Belut Segar Buffer PBS, BRTG = Belut Rebus Buffer Tris Glisin, BRTGD $=$ Belut Rebus Buffer Tris Glisin DTT, BRPBS= Belut Rebus Buffer PBS

Gambar 2. Profil SDS-PAGE Ekstrak protein belut sawah
Intensitas pita protein terbesar pada BSTG adalah protein dengan BM $26 \mathrm{kDa}$ sebesar 13,6\%, pada BSTGD $26 \mathrm{kDa}$ sebesar 17\%, BSPBS $25 \mathrm{kDa}$ sebesar 12,6\%, BRTG $80 \mathrm{kDa}$ sebesar 23,6\%, BSTGD pada $26 \mathrm{kDa}$ sebesar 13,5\% dan BRPBS pada $75 \mathrm{kDa}$ sebesar 14,8\%. Berdasarkan penelusuran di database WHO/IUIS Allergen Nomenclatur, belut sawah belum memiliki data alergennya.

\subsection{IgE total dan IgE spesifik}

IgE total menunjukkan jumlah antibodi IgE yang ada dalam serum penderita alergi. Analisis IgE spesifik dari belut sawah pada 10 subjek ini menggunakan metode ELISA (Zakaria et al. 1993 I). Metode ini cukup baik digunakan karena dapat menunjukkan reaktivitas IgE spesifik dengan serum IgE pada konsentrasi yang rendah (Astuti et al. 2015, Astuti et al. 2018). Pada metode ini, isolat protein diikatkan pada lempeng mikrotiter ELISA dan diinkubasi dengan serum penderita alergi (Nirbaya et al. 2020). Hasil analisis IgE total dari 10 subjek positif alergi pangan dapat dilihat pada Gambar 3.

Dari hasil IgE total terlihat bahwa seluruh subjek menderita alergi yang ditunjukkan dengan nilai absorbansi yang lebih besar dari kontrol negatif. Semua hasil analisis IgE total subjek menunjukkan bahwa semua subjek merupakan penderita alergi dengan tingkat alergi yang berbeda-beda. Pada Gambar 6 terlihat bahwa responden yang memiliki tingkat alergi yang paling tinggi adalah subjek 5 dan responden yang memiliki tingkat alergi paling rendah adalah subjek 6. Semakin besar IgE total seseorang menunjukkan bahwa tingkat alerginya semakin tinggi (Zakaria 1998).

Antibodi IgE dalam serum yang dapat berikatan dengan isolat protein merupakan antibodi IgE spesifik terhadap protein isolat sebagai alergennya. Nilai IgE spesifik yang tinggi menunjukkan pengikatan yang kuat antara IgE subjek penderita alergi dengan protein alergen tertentu secara spesifik (Chalid et al. 2020). Hasil analisis IgE spesifik dari protein belut sawah terlihat bahwa 10 subjek positif alergi terhadap belut segar maupun belut rebus (Tabel 1). 


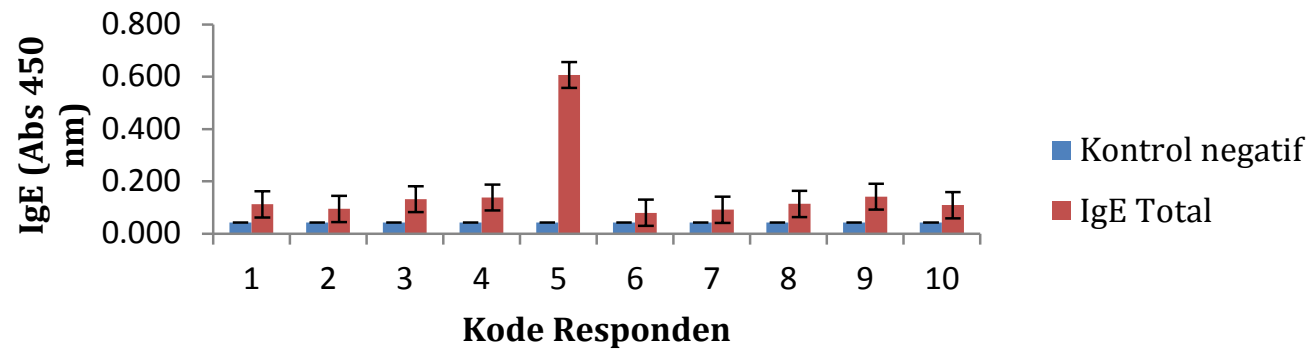

Gambar 3. Analisis IgE total pada 10 serum responden penderita alergi

\subsection{Immunoblotting}

Penelitian ini menggunakan 10 subjek positif alergi yang diambil serumnya. Hasil immunoblotting menunjukkan berat molekul protein yang dapat menyebabkan alergi (Chalid et al. 2020). Dari hasil imunoblotting subjek 2, 4 dan 8 memberikan reaksi positif. Subjek 2 positif pada belut segar buffer PBS (BSPBS), subjek 4 pada sampel belut segar buffer Tris Glisin (BSTG), belut segar buffer TGD (BSTGD) dan belut segar buffer PBS (BSPBS) serta subjek 8 pada sampel BSTGD, BSPBS, belut rebus buffer TG (BRTG) dan belut rebus buffer TGD (BRTGD). Hasil immunoblotting yang dihasilkan dianalisis dengan software Gelanalyzer 2010a. Pada subjek 2, antibodi IgE yg terdapat dalam serum subjek mengikat belut segar buffer PBS (BSPBS) pada pita protein $101 \mathrm{kDa}$ (Gambar 3).

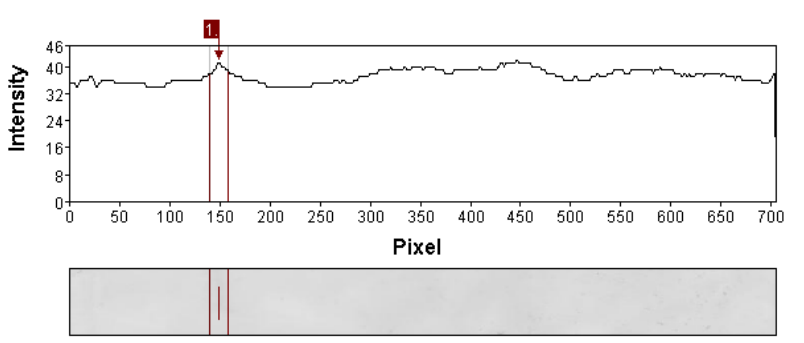

Gambar 4. Hasil Immunoblotting isolat protein belut segar buffer PBS pada subjek 2 setelah dianalisis dengan software analyzer $2010 \mathrm{a}$

Pada subjek 4, antibodi IgE yang berikatan dengan alergen pada belut segar buffer PBS (BSPBS pada berat molekul $78 \mathrm{kDa}$, belut segar buffer TGD (BSTGD) pada berat molekul $25 \mathrm{kDa}$, dan belut segar buffer TG (BSTG) pada berat molekul $25 \mathrm{kDa}$ (Gambar 4).

Pada subjek 8, antibodi IgE subjek bereaksi positif pada Belut segar buffer TGD (BSTGD) yaitu pada pita protein $29 \mathrm{kDa}$ dan 3 pita protein $23 \mathrm{kDa}$, belut segar buffer PBS (BSPBS) pada pita protein 51 $\mathrm{kDa}$ belut rebus buffer TG (BRTG) pada pita protein $23 \mathrm{kDa}$, dan belut rebus buffer TGD (BRTGD) pada pita protein $23 \mathrm{kDa}$. Dari hasil immunoblotting ini dapat terlihat bahwa ekstrak protein belut bersifat alergenik pada subjek namun pengikatannya pada protein yang berbeda-beda.

\subsection{Reaktivitas isolat protein pada uji tusuk kulit}

Uji Tusuk Kulit dilakukan oleh tim dokter dari Klinik Alergi dan Asma DR. Indrajana Tanah Abang Jakarta. Reagen untuk uji tusuk kulit telah memenuhi syarat European Pharmacopoeia 7.0 monograph on allergen product 01/2010:1063, karena telah diuji sterilitasnya terhadap bakteri, kapang dan khamir dan tidak terdeteksi adanya bakteri Pseudomonas aeruginosa dan Staphylococcus aureus. Reagen yang berisi isolat protein belut sawah ini ditusukkan ke lapisan kulit subjek penderita alergi dan menimbulkan reaksi berupa bentol (Gambar 6).

Hasil uji tusuk kulit memperlihatkan timbulnya bentol kemerahan pada kulit, hal terjadi karena adanya cross-linked atau ikatan silang antara alergen belut sawah yang digunakan dengan IgE yang terikat pada sel mastosit dari subjek penderita alergi sehingga menyebabkan keluarnya histamin dan mediator lain dari sel mastosit yang menyebabkan vasodilatasi dan peningkatan permeabilitas pembuluh darah sehingga pada kulit timbul kemerahan dan bentol (Wijaya et al. 2015).

Tabel 1 menunjukkan bahwa terdapat variasi hasil antara IgE spesifik dengan hasil uji tusuk kulit. Ini terlihat dari hasil uji tusuk kulit yang negatif sedangkan hasil IgE spesifik yang positif. Pada subyek 5 misalnya, dari hasil IgE spesifik belut segar maupun belut rebus dengan metode ELISA menunjukkan hasil yang positif namun hasil uji tusuk kulit memperlihatkan hasil yang negatif. Perbedaan ini menunjukkan sensitivitas dari alergen yang dibuat. Ukuran bentol dinyatakan 0 bila ukuran bentol sama dengan kontrol negatif (tidak terbentuk bentol). Hasil dinyatakan +1 bila ukuran bentol 25 $50 \%$ lebih besar dari kontrol negatif $(<3 \mathrm{~mm})$. Hasil +2 bila ukuran bentol 50-75\% lebih besar dari kontrol negatif $(3-5 \mathrm{~mm}),+3$ bila ukuran bentol sama besar dengan kontrol positif (5-7 mm) dan +4 bila ukuran bentol 25-50\% lebih besar dari kontrol positif dan $>+4$ bila ukuran bentol lebih dari 50\% dari kontrol positif (Wijaya et al 2015). 


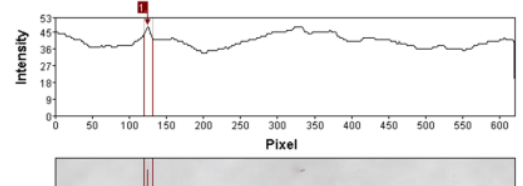

BSPBS

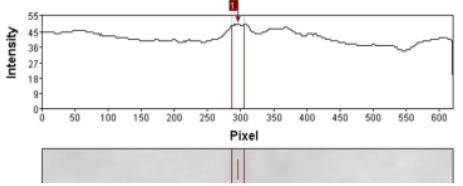

BSTGD

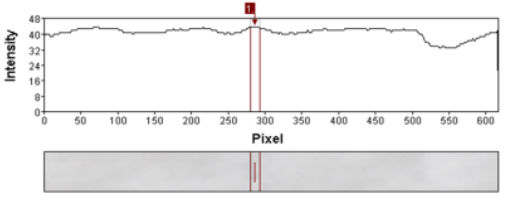

BSTG

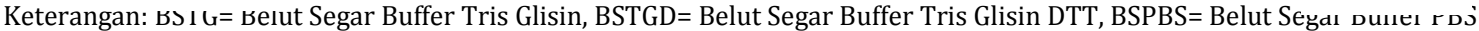
Gambar 5. Hasil Immunoblotting Belut segar buffer TG, TGD dan PBS pada Subjek 4 Setelah Dianalisis dengan Software Gelanalyzer 2010a

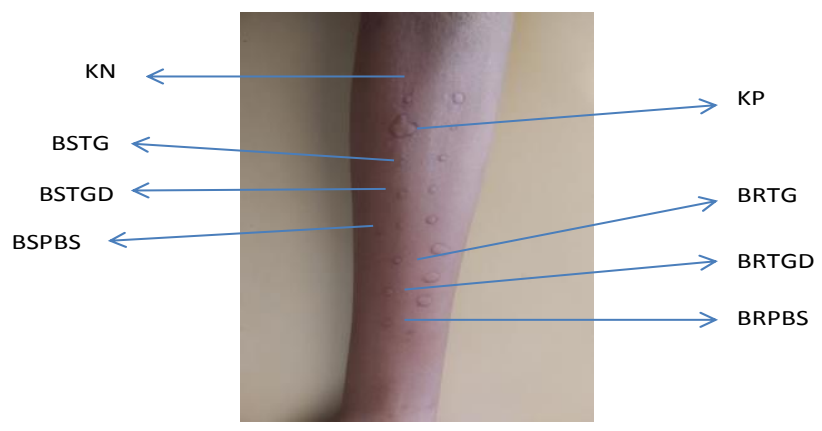

Keterangan: KN=Kontrol Negatif, KP=Kontrol Positif, BSTG= Belut Segar Buffer Tris Glisin, BSTGD= Belut Segar Buffer Tris Glisin DTT, BSPBS= Belut Segar Buffer PBS, BRTG = Belut Rebus Buffer Tris Glisin, BRTGD= Belut Rebus Buffer Tris Glisin DTT, BRPBS= Belut Rebus Buffer PBS

Gambar 6. Hasil uji tusuk kulit alergen belut segar dan belut rebus

Tabel 1 Hasil pengukuran IgE total, IgE spesifik dan uji tusuk kulit subyek alergi belut sawah

\begin{tabular}{|c|c|c|c|c|c|c|c|c|c|c|c|c|c|}
\hline \multirow{2}{*}{ Responden } & \multirow{2}{*}{$\begin{array}{c}\text { Hasil } \\
\text { IgE } \\
\text { total } \\
\end{array}$} & \multicolumn{6}{|c|}{ Hasil IgE spesifik } & \multicolumn{6}{|c|}{ Hasil Uji Tusuk Kulit (UTK) } \\
\hline & & BSTG & BSTGD & BSPBS & BRTG & BRTGD & BRPBS & BSTG & BSTGD & BSPBS & BRTG & BRTGD & BRPBS \\
\hline 1 & + & + & + & + & + & + & + & +1 & +1 & +1 & +1 & +1 & +1 \\
\hline 2 & + & + & + & + & + & + & + & +3 & +2 & +3 & +2 & +1 & - \\
\hline 3 & + & + & + & + & + & + & + & +4 & +3 & +1 & +2 & - & - \\
\hline 4 & + & + & + & + & + & + & + & - & - & - & - & +1 & +1 \\
\hline 5 & + & + & + & + & + & + & + & - & - & - & - & - & - \\
\hline 6 & + & + & + & + & + & + & + & +1 & - & - & - & - & - \\
\hline 7 & + & + & + & + & + & + & + & +1 & - & - & - & - & - \\
\hline 8 & + & + & + & + & + & + & + & - & - & - & - & - & +1 \\
\hline 9 & + & + & + & + & + & + & + & - & +1 & - & +1 & +1 & - \\
\hline 10 & + & + & + & + & + & + & + & - & +1 & - & - & +1 & +1 \\
\hline
\end{tabular}

Keterangan: BSTG= Belut Segar Buffer Tris Glisin, BSTGD= Belut Segar Buffer Tris Glisin DTT, BSPBS= Belut Segar Buffer PBS, BRTG = Belut Rebus Buffer Tris Glisin, BRTGD= Belut Rebus Buffer Tris Glisin DTT, BRPBS= Belut Rebus Buffer PBS

\section{Kesimpulan}

Hasil SDS PAGE belut rebus (BR) menunjukkan jumlah pita protein yang lebih sedikit dibandingkan dengan belut segar (BS). Pemilihan Buffer yang sesuai dalam mengekstraksi protein alergen belut sawah dapat meningkatkan rendemen sehingga semakin banyak ekstrak protein alergen yang didapatkan. Protein yang tinggi merupakan salah satu faktor yang menentukan alergenitas. Ekstrak protein yang diperoleh diuji alergenisitas proteinnya dengan metode ELISA dan memperlihatkan adanya alergenitas. Ekstrak protein belut juga mempunyai kemampuan mengikat IgE pada serum subjek sehingga dapat digunakan untuk pembuatan alergen uji tusuk kulit. Hasil SPT menunjukkan bahwa proses perebusan dapat menurunkan alergenitas. 


\section{Ucapan Terima Kasih}

Penulis mengucapkan terimakasih kepada tim komisi pembimbing yaitu Prof Dr. Fransiska Zakaria-Rungkat, MSc, Dr. Endang Prangdimurti M.Si, dan Dr, Hendra Wijaya M.Si atas bimbingannya sehingga penelitian ini bisa diselesaikan dengan baik. Terimakasih juga penulis ucapkan kepada LPDP BUDIDN yang telah memberikan beasiswa kepada penulis.

\section{Daftar Pustaka}

[AOAC] Analysis of the Association of Official Agriculture Chemistry. 1998. Nitrogen (Total) (crude protein) in plants, kjeldahl methods. Methods 955.04. Ed ke-18. USA: AOAC International

Astiana I, Nurjanah, Suwandi R, Suryani AA, Hidayat T. 2015. Pengaruh penggorengan belut sawah (monopterus albus) terhadap komposisi asam amino, asam lemak, kolesterol dan mineral. Depik. 4(1): 49-57 doi: Http://Dx.Doi.Org/10.13170/Depik.1.1.2365

Astuti, R.M., Palupi, N.S., Zakaria-Rungkat F. 2016. Allergic reactivity of bambara groundnut (Vigna subterranea) proteins. Food and Agricultural Immunology. 27 (4):535-546.

Astuti, R.M., Palupi, N.S., Zakaria-Rungkat F. 2018. Quality performance of protein allergen isolates for allergy diagnostic test (case: indonesian soybeans (Glycine max) and peanuts (Arachis hypogaea). International Food Research Journal. 25(1): 217-226.

Chalid SY, Zakaria-Rungkat F, Syah D, Giriwono PE (2020) Sensitivitas ekstrak protein kacang tanah (Arachis hypogea l.) sebagai larutan uji tusuk kulit. Warta IHP. 37(2):124-132.

Chapman, Bernstein,. Lee R, Oppenheimer J. 2006. Food Allergy: A Practice Parameter. Annals of Allergy, Asthma \& Immunology.

Ilyas FS dan Waspodo NN. 2010. Panduan peserta uji tusuk kulit menggunakan alergen standar. Update in pathogenesis, diagnostic test and treatment simposium dan workshop. Makasar: RS Akademis Jaury Jusuf Putra.

Jeong KY, Choi SY, Han IS, Lee JH, Lee JS, Hong CS, Park JW. 2013. The effects of storage conditions on the stability of house dust mite extracts . Allergy Asthma Immunol. 5(6):397401.

Http://Dx.Doi.Org/10.4168/Aair.2013.5.6.397.

Kumar R, Kumari D, Srivastava P, Khare V, Fakhr H, Arora N, Gaur SN, SinghBP. 2010. Identification of IgE-mediated food allergy and allergens in older children and adults with asthma and allergic rhinitis. Indian J Chest Dis Allied Sci. 52(4):217-224.
Laemmli UK. 1970. Cleavage of structural protein during the assemby of the head of bacteriophage T4. Nature. 227: 680-685.

Ma Jiaju, Pavase TR, Li Zhen Xing, Lin Hong. 2017. Optimisation of an extraction techniqueof fish allergens suitable for detection and diagnosis. Czeh J. Food Sci. 35(1):24-31. Doi: 10.17221/578/2015-CJFS.

Pawankar Holgate ST, Rosenwasser LJ, editor. 2009. Allergy frontiers: classification and pathomechanisms. Vol ke-2. Tokyo: Springer.

Maleki SJ, Casillas AM, Kaza U, Wilson BA, Nesbit JB, Reimoneqnue C, Cheng H, Bahna SL. 2010. Differences among heat-treated, raw, and commercial peanut extracts by skin testing and immunoblotting. Ann Allergy Asthma Immunol. 105(6): 451-457. doi: 10.1016/j.anai.2010.09.025.

Nirbaya A, Wijaya H, Zakaria-Rungkat F. 2020. Stability of bioactive compound and fatty acid composition after thermal processing of winged bean (Psophocarpus tetraglonolobus). International Journal of Advanced Science and Technology. 29(7) : 1602-1610.

Nirbaya A, Zakaria-Rungkat F. 2021. Immunomodulatory potentials of winged Bean (Psophocarpus tetragonolobus) bioactive compounds on human lymphocyte proliferation. International Journal on Advanced Science Engineering Information Technology. 11(3):849-855. DOI: 10:18517/ijaseit.11.3.11527

Palupi NS, Sitorus SR, Kusnandar F. 2015. Perubahan alergenitas protein kacang kedelai dan kacang bogor akibat pengolahan dengan panas. J. Teknol dan Industri Pangan. 26(2):222-231. DOI:10.6066/jtip.2015.26.2.222.

Purbasari D. 2012. Isolasi dan karakterisasi protein ikan tongkol (Auxis thazard), kerang hijau (Perna viridis) dan udang jerbung (Penaeus merguiensis) untuk pembuatan isolat alergen [Tesis]. Bogor: Fakultas Teknologi Pertanian, Institut Pertanian Bogor.

Sampson H.A. 2002. Peanut allergy. The New England J. Med. 346: 1294-1299.

Sundari D, Almasyhuri, Lamid A. 2015. Pengaruh proses pemasakan terhadap komposisi zat gizi bahan pangan sumber protein. Media Litbangkes. 4(25): 235-242.

Suseno R, Palupi NS, Prangdimurti E. 2016. Alergenitas sistem glikasi isolat protein kedelai-fruktooligosakarida. Agritech. 36(4) 450-458.

Doi:http://dx.doi.org/10.22146/agritech.1677 0.

Van Hangel A. 2007. Food allergen detection methods and the challenge to protect food- 
allergic consumers. Anal. Bioanal. Chem. 389:111-118.

Vissers YM, Blanc F, Skov PS, Johnson PE, Rigby NM, Nicaise LP, Bernard H, Wal JM, Weber BB, Jongejan LZ Sze ZP, Koerts JR, Jansen AP, Savelkoul HFJ, Wichers HJ, Mackie AR, Mills CEN, Patient KA. 2011. Effect of heating and glycation on the allergenicity of $2 \mathrm{~S}$ albumins (Ara h 2/6) from peanut. PloS One. 6 (8): 1-9.

Wijaya H, Zakaria-Rungkat F, Syah D , Prangdimurti E. 2014. Extraction of squid (Photololigo Duvaucelii) myofibrillar and sarcoplasmic proteins to create a skin prick test reagent in the diagnosis of food allergy. Journal of Pharmacy. 4(9): 06-14.

Wijaya H, Zakaria-Rungkat F, Syah D, Prangdimurti E. 2015. Extraction of crab (Scylla serrata) myofibrillar and sarcoplasmic proteins to create a skin prick test reagent for crab allergy diagnosis. Procedia Food Science. 3: 52 - 68

Yusnawan E, Marquis Cp, Lee Na. 2013. Isu global keamanan pangan kacang tanah ii: protein ara h sebagai alergen. Buletin Palawija. 26: 72-82.

Zakaria-Rungkat F, Khatib A, Ispurwanto, Rahman A. 1998. Telaah sifat alergenisitas udang putih (Penaeus marguensis) untuk produksi isolat alergen. Bul Teknol dan Industri Pangan. 9: 5459.

Zakaria-Rungkat F, Nabet P, Belleville F, Linden G.1993. Allergenicity of bovine casein. I. Specific lymphocyte proliferation and antibody production as results of casein feeding in casein free mice. Food Agriculture Immunology. 4: 41-51.

Zakaria-Rungkat F, Nabet P, Belleville F, Linden G.1993. Allergenicity of bovine casein. II. Specific lymphocyte proliferation and histamine accumulation in the mastocyte as results of casein feeding in mice. Food Agriculture Immunology. 4: 52-67 